\title{
ENCEPHALITIS DURING TREATMENT OF LOIASIS WITH DIETHYLCARBAMAZINE
}

\author{
Lieutenant-Colonel C. G. B. DOWNIE \\ B.Sc., M.B., M.R.C.P., M.R.C.P.(Edin.), D.T.M.\& H., R.A.M.C.
}

ENCEPHALITIS is a rare complication of loiasis which is not well recognised, although it has been reported as arising after administration of diethylcarbamazine (Van Bogaert, Dubois, Janssens, Radermecker and Wansom, 1955; Pande, 1962), and as occurring spontaneously but becoming more severe after starting treatment with this drug (BertrandFontaine, Schneider, Wolfram and Gagnard, 1948; Kivits, 1952; Alajouanine, Castaigne, Lhermitte and Cambier, 1959; Cattan, Frumusan and Levy, 1960). It has also occurred in bancroftian filariasis (Kenney and Hewitt, 1950).

There is only one recorded recovery from this type of encephalitis before the use of steroids. The present case from Nigeria is presented to illustrate a dramatic response and so that the condition may be more readily diagnosed and successfully treated in the future.

\section{Case Report}

A 20 year old Hausa male recruit of the Royal Nigerian Army complained of an irritating papular skin rash on 9th May, 1960. Microfilariae of Onchocerca volvulus were seen in skin snips. He was given diethylcarbamazine, $50 \mathrm{mg}$. on the first day, and $100 \mathrm{mg}$. on the second. On the third day the pruritus became worse and he developed a fever. The diethylcarbamazine was continued at $100 \mathrm{mg}$. daily together with promethazine hydrochloride $25 \mathrm{mg}$. twice daily, with some relief. However on the next morning he was drowsy and he became deeply unconscious within a few hours. He was then admitted to hospital in Kaduna.

On admission he was comatose, responding only to pain, and with marked neck stiffness. He could swallow fluids, but was incontinent of both urine and faeces. The corneal reflexes were present, the pupils regular, equal and reacting normally, the ocular fundi were normal as was examination of the remaining cranial nerves. Abdominal reflexes were absent, muscle tone and tendon reflexes were increased on the right side, with an extensor plantar response.

The temperature was $101.4^{\circ} \mathrm{F}$. $\left(38.5^{\circ} \mathrm{C}\right.$.), and the pulse regular 84 beats per minute. Further clinical examination was normal.

\section{Investigations:-}

Urine - trace of protein, occasional white cell on microscopy, negative on culture.

Blood-haemoglobin was $14.0 \mathrm{~g}$. per $100 \mathrm{ml}$., total white cell count 6,200 (polymorphs $48 \%$, lymphocytes $36 \%$, eosinophils $12 \%$, monocytes $4 \%$ ). Microfilariae loa present in large numbers, no trypanosomes.

Blood sugar-90 mg. per $100 \mathrm{ml}$. blood urea $-46 \mathrm{mg}$. per $100 \mathrm{ml}$. Blood Kahn negative.

Cerebrospinal fluid-clear and colourless, pressure $120 \mathrm{c} . \mathrm{mm}$. of water, $80 \mathrm{lym}$ phocytes per c. mm., no red blood cells, protein $60 \mathrm{mg}$. per $100 \mathrm{ml}$. No trypanosomes or microfilariae. 
Clinical progress:-

No significance was attached to the presence of $M$. loa and treatment was started with tetracycline and penicillin, and intravenous fluids. There was no improvement for 6 days, but the neurological signs varied from day to day. He sometimes presented the picture of a spastic paraplegia with bilateral extensor plantar responses; at other times muscle tone and tendon reflexes would be normal; or his original right-sided spastic hemiplegia would recur. The level of consciousness fluctuated only slightly, but he would respond occasionally by movement to a loud shout. The neck stiffness became progressively less marked. The cerebrospinal fluid was examined on two further occasions with similar results.

On the 6th day chloramphenicol was substituted for tetracycline and penicillin, but there was no change. On the 10th day the laboratory reported that the number of $M$. loa in the peripheral blood had increased so that it was greater than any of the staff had seen before. It was now considered that the loiasis might be responsible for the whole clinical picture. The chloramphenicol was therefore stopped; and, since the patient was weakening, prednisolone and diethylcarbamazine were given together orally in the following dosage:

$\begin{array}{lcc} & \text { Prednisolone } & \text { Diethylcarbamazine } \\ \text { Day 1. } & 80 \mathrm{mg} . & 100 \mathrm{mg} . \\ \text { Day } 2 . & 60 \mathrm{mg} . & 200 \mathrm{mg} . \\ \text { Day 3. } & 60 \mathrm{mg} . & 400 \mathrm{mg} . \\ \text { Day 4. } & 60 \mathrm{mg} . & 600 \mathrm{mg} .\end{array}$

Improvement was obvious within 24 hours. The temperature, which had not been below $101^{\circ} \mathrm{F}$. $\left(38.3^{\circ} \mathrm{C}\right.$.) before, fell rapidly to normal and on the second day of treatment the patient was able to sit up and take food, and he regained control of his sphincters. By the end of the third day he was able to talk and get out of bed. The dose of diethylcarbamazine was continued at $600 \mathrm{mg}$. daily (approximately $9 \mathrm{mg} . / \mathrm{kg}$. body weight), and after 10 days the dose of prednisolone was gradually reduced. He had no relapse and after 21 days all treatment was stopped without ill effect.

There were now no abnormal neurological signs. The cerebrospinal fluid contained 10 lymphocytes per c. mm., and $50 \mathrm{mg}$. of protein per $100 \mathrm{ml}$. There were no microfilariae on repeated examination of the peripheral blood. His mental state however remained abnormal. He was emotionally labile, with fits of laughing and weeping, and there was an obvious degree of dementia which was still present after six weeks.

\section{Discussion}

The clinical features, and the findings in the blood and cerebrospinal fluid, in the reported cases of encephalitis occurring in patients suffering from filariasis are summarised in Table 1. Fever and confusion or coma were present in all 12 patients. Hemiplegia occurred in 8 , and neck stiffness in 6 . The blood eosinophil count varied from nil to 7,600 . The cerebrospinal fluid contained microfilariae in 6 patients, but the cell count and protein were normal or only slightly raised.

Three patients received no specific treatment and all died. Five were treated with diethylcarbamazine alone and four died. The remaining four received steroids as well and all survived. The patient described by Pande (1962) was the only one to be given a steroid early and he was the only one to recover completely. The other three steroidtreated patients were all given the steroids after some delay because of failure to recognise the condition, and all were left with neurological or mental deficit. 


\begin{tabular}{|c|c|c|c|c|c|c|c|c|c|c|}
\hline \multirow{2}{*}{$\begin{array}{lll} & \\
\ddots & \end{array}$} & \multicolumn{3}{|c|}{ Clinical Condition } & \multicolumn{2}{|c|}{ Blood } & \multicolumn{2}{|r|}{ C. S.F. } & 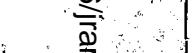 & \multirow{2}{*}{$\begin{array}{l}\text { Treat } \\
\text { ment }\end{array}$} & \multirow{2}{*}{ Result } \\
\hline & $\begin{array}{c}\text { Conscious } \\
\text { State }\end{array}$ & $\begin{array}{c}\text { Neck } \\
\text { Stiffness }\end{array}$ & $\begin{array}{l}\text { Neurological } \\
\text { Syndrome }\end{array}$ & $M f$ & $\begin{array}{c}\text { Eosinophil } \\
\text { count }\end{array}$ & $\begin{array}{c}\text { Cells } \\
\text { per mm. }\end{array}$ & $\begin{array}{c}\text { Protein } \\
m g . / 100 m l .\end{array}$ & $\begin{array}{r}\text { Bloo } \\
\quad \text { filaria } \\
\text { filar }\end{array}$ & & \\
\hline Bonnet (1943) & Coma & + & $\begin{array}{l}\text { Unilateral } \\
\text { extensor plantar }\end{array}$ & + & $?$ & 26 & 40 & $\Leftrightarrow \Phi+$ & & Died in 4 days \\
\hline Kivits (1952) 1 . & Coma & 0 & $\begin{array}{l}\text { No localising } \\
\text { signs }\end{array}$ & ? & $?$ & 5 & 12 & $0_{0}^{\infty}=4$ & 0 & Died in 5 days \\
\hline$\because$ & Coma & 0 & $\begin{array}{l}\text { Generalised } \\
\text { spasticity }\end{array}$ & + & . nil & 5 & 20 & 兽 & & Died in 5 days \\
\hline $\begin{array}{l}\text { Bertrand-Fontaine } \\
\text { (1948) }\end{array}$ & Confused & 0 & Hemiplegia & + & $\begin{array}{r}\text { eosino- } \\
\text { philia }\end{array}$ & $\mathbf{N}$ & $\mathbf{N}$ & $\sum_{0}^{0} 0$ & & $\begin{array}{l}\text { Survived with slight } \\
\text { disability }\end{array}$ \\
\hline $\begin{array}{l}\text { Kenney \& } \\
\text { Hewitt (1950) }\end{array}$ & Confused & $?$ & Hemiplegia & $?$ & $?$ & $?$ & $?$ & ? & & Died in 7 dayś \\
\hline Kivits (1952) 3. & Stuporose & 0 & $\begin{array}{l}\text { Unilateral } \\
\text { extensor plantar }\end{array}$ & + & ?? & 30 & 30 & $0+4$ & D & Died in 5 days \\
\hline$" \quad 4$ & Stuporose & $t$ & $\begin{array}{l}\text { Generalised } \\
\text { spasticity }\end{array}$ & + & $15 \%$ & 8 & 20 & $0 \$+$ & & Died in 18 days \\
\hline Van Bogaert (1955) & Coma & + & Hemiplegia & ++ & 1270 & $\mathbf{N}$ & $N$ & $0 \%+$ & & Died in 8 days \\
\hline Alajouanine (1959) & Confused & 0 & $\begin{array}{l}\text { Ataxia, unilateral } \\
\text { hyper-reflexia }\end{array}$ & 0 & 7600 & $\mathbf{N}$ & $\mathbf{N}$ & 0 变 0 & & $\begin{array}{l}\text { Survived with post- } \\
\text { encephalitic state }\end{array}$ \\
\hline Cattan (1960) & Stuporose & t & Ataxia & $t++$ & 2500 & 2 & 20 & ? 拝 0 & $D+S$ & $\begin{array}{c}\text { Survived with post } \\
\text { encephalitic state }\end{array}$ \\
\hline Pande (1962) & Coma & + & $\begin{array}{l}\text { Unilateral } \\
\text { extensor plantar }\end{array}$ & + & 570 & 5 & 30 & $0 \stackrel{0}{\Phi_{1}} 0$ & & Full recovery \\
\hline Present case & Coma & + & $\begin{array}{l}\text { Spastic } \\
\text { hemiplegia }\end{array}$ & +++ & 740 & 80 & 60 & $0 \frac{8}{8} 0$ & & $\begin{array}{l}\text { Survived with } \\
\text { mental defect }\end{array}$ \\
\hline
\end{tabular}

TABLE 1. Clinical, blood, and CSF findings in cases of filarial encephaitis.

$\mathrm{O}=$ nil, or absent

$?=$ no information

$\mathrm{N}=$ normal
Treatment : $O=$ no specific treatment

$\mathrm{D}=$ Diethylcar Eamazine

$\mathrm{S}=$ Steroids
กิ

กิ 
Encephalitis is a rare complication of filariasis, because it is probable that microfilariae do not usually penetrate the brain tissue. Van Bogaert et al (1955) agreed, with Kivits (1952) that penetration might occur through the walls of damaged cerebral capillaries in the presence of coincident malaria, trypanosomiasis, or syphilis. These authors were able to demonstrate microfilariae in the brain tissue at autopsy. Diethylcarbamazine frequently increases the severity of filarial inflammatory lesions and might well give rise to a clinical encephalitis in patients in whom microfilariae had penetrated the brain. Encephalitis may occur even though diethylcarbamazine is given initially in small doses, as in the present case (because of coincident onchocerciasis), and in the patient described by Pande (1962) in whom $100 \mathrm{mg}$. appears to have been enough to provoke the condition. Therefore patients with bloodborne filariasis should be kept under observation during the first 72 hours of treatment with diethylcarbamazine, or instructed to report at once if headache, sleepiness, or paralysis occur, and in this event steroids should be given in full doses.

\section{Summary}

The occurrence of severe encephalitis apparently provoked by the use of diethylcarbamazine in the treatment of loaisis is reported.

This is a rare but serious complication of filariasis, commoner in loaisis, but also occurring in infections with Wuchereria species. The danger period is the first 72 hours of treatment. The condition was usually fatal before steroids were used in treatment.

Prednisolone in full dosage is a rapidly effective treatment, and the antifilarial drug - may be given concurrently.

\section{REFERENCES}

Alajouanine, T., Castaigne, P., Lhermitte, F. and Cambier, J. (1959). Rev. neurol. 101, 656.

Bertrand-Fontaine, (Mme), Schneider, J., Wolfram, R. and Gagnard, V. (1948). Bull. Soc. Med. Paris. 64, 1092.

BonNeT, R. (1943). Med. Trop. Marseille. 4, 273 .

Cattan, R., Frumusan, P and Levy, C. (1960). Bull. Soc. Med. Paris. 76, 808.

KenNEY, M. and HEWITT, R. (1950). Amer. J. trop. Med. 30, 895.

KIVITS, M. (1952). Ann. Soc. Belge. Med. trop. 32, 235.

Pande, R. S. (1962). J. Ass. Phys. India. 10, 469.

VAN Vogaert, L., Dubois, A., JansSens, P. G., Radermecker, J., TVerdy, G. and Wansom, M. (1955). J. Neurol. Neurosurg. Psych. 18, 103.

\section{World Health Organization}

Dr. M. A. C. Dowling who has been appointed Medical Officer in the Planning and Programme Unit of the Division of Malaria Eradication at W.H.O. Headquarters, will be remembered during his service with the Corps. He joined W.H.O. in 1957 and has since been concerned with planning and training activities in Africa.

\section{University of London}

The appointment of Dr. Herbert Spencer as professor of morbid anatomy at St. Thomas's Medical School has been announced.

He served with R.A.M.C. from $1 \overline{9} 42$ to 1947 and was four years in Egypt, Iraq and 'Paiforce '. A specialist in pathology he became A.D.P. G.H.Q., M.E.F., and was for a time demonstrator in pathology at R.A.M. College. 